\title{
Local Governance: A Correlational Study of Administrative Capability and Performance
}

\author{
Rogelio D. Mercado \\ Institute of Graduate and Advanced Studies, Urdaneta City University, 108 SLU-SVP \\ Housing Village, Old Site, Bakakeng, Baguio City, Philippines
}

\begin{abstract}
This study explored the level and correlation of administrative capability and performance of local governments in northern Philippines, particularly in the Cordillera Region. This inquiry utilized the descriptive-co-relational design involving respondents from selected provinces of the region. The results revealed that the respondents gave a low assessment of the different dimensions of administrative capability. The results also showed dissatisfaction of the performance of the local governments. The tests conducted manifested that there is a significant relationship between administrative capability and performance. Social responsibility appeared to be the most dominant dimension that is linked to performance while organization structure emerged to be the least relevant. Generally, the results imply that as administrative capability improves, performance becomes more effective. On the whole, the findings of this investigation connote that with a strong sense of social responsibility, local governments can deliver services regardless of their organization structure.
\end{abstract}

Keywords: Administrative capability, Performance, Local governments

DOI: $10.7176 /$ PPAR/11-3-02

Publication date: April $30^{\text {th }} 2021$

\section{Introduction}

Good governance is a common public utterance among development actors and institutions all over the world. It is a common belief among major development institutions today that promoting good governance is an important part of their agenda.

The most common governance initiative is decentralization. As the United Nations Development Programme (Altmann, et al, 2000) stressed, "decentralizing government enables people to participate more directly in governance processes and can help empower people previously excluded from decision-making."

Many countries have embraced decentralization over the past two decades especially among the developing states. In Southeast Asia, decentralization was designed to bring a measure of autonomy to Indonesia's many culturally diverse regions. True democratic decentralization in Indonesia, however, has not occurred and the present attempt has been co-opted to a certain extent by Suharto-era bureaucrats, politicians, and business people (Green, 2005).

In the Philippines, one of the major state policies provided in the 1987 Constitution declared that "the state shall ensure the autonomy of local governments." For this purpose, Sec. 3, Art. X specifically mandated the Congress to "enact a local government code which shall provide a more responsive and accountable local government structure instituted through a system of decentralization with effective mechanisms of recall, initiative, referendum, allocate among the different local government units their powers, responsibilities and resources, and provide for the qualifications, election, appointment and removal, term, salaries, powers and functions and duties of local officials and all other matters relating to the organization and operation of local units (Aralar, 2009)."

Pursuant to this Constitutional mandate, the Local Government Code (LGC) of 1991 was formulated and subsequently signed into law on October 10, 1991.

The Code put into effect meaningful decentralization and autonomy by recognizing the key role of local governments in the implementation of public programs and the delivery of basic services. More power, authority, responsibilities, and resources were provided to local governments aimed at accelerating development and progress in the countryside. This move put to the test the administrative capability of the local governments in the performance of their expanded functions.

According to Palekar (2012), administrative capability refers to the ability of organizations to carry out the required tasks in order to achieve the desired goals.

Katz (2010) said administrative capability for development involves the ability to mobilize, allocate, and combine the actions that are technically needed to achieve development objectives.

Meanwhile, De Guzman and Reforma (1993) identified leadership, structure, financial resources, and personnel as the dimensions of administrative capability.

According to Corpuz (2006), performance is the accomplishment of an employee or manager's assigned duties and the outcomes produced on a specified job function or activity during a specified time period. It is an indicator of whether goals or objectives have been satisfied or not. This means that the measure of performance 
is closely associated with task accomplishment.

Administrative capability then of organizations including local governments is a major component in the effective performance of any development initiative.

\section{Statement of the Problem}

After almost three decades since the enactment of the Philippine Local Government Code, some local governments appeared to have surmounted the numerous issues and concerns that surfaced during the first few years of the Code's implementation as proven by the various innovations undertaken in the past several years which now serve as models of good governance. On the other hand, a number of local governments still could not seem to keep pace with the demands of the devolved powers and functions.

Still, a number of local governments could not seem to keep pace with the demands of the devolved powers and functions. A solid proof is the list of the 15 poorest provinces where more than $40 \%$ of the families lived below the poverty threshold. Prepared regularly by the National Statistical Coordination Board (NSCB), the list always included the provinces of the Cordillera Administrative Region (CAR). The latest list showed Apayao at number 2 and Ifugao at number 7.

With a poor showing in poverty alleviation and performance, it appears that the local governments in the region are confronted with capacity issues that are required to institute administrative innovation and reform in spite of the autonomy they now enjoy and the presence of immense natural resources.

The seriousness of the problems besetting the region necessitates the availability of a capable administrative mechanism in order to improve local government performance. An assessment then of the administrative capability of the local governments to perform their powers and functions as provided by the Code is timely.

Although several studies were undertaken in the past relative to the autonomy enjoyed by local governments, most were devoted to assessments of the nature of the devolved powers and functions.

Utilizing the dimensions of administrative capability forwarded by De Guzman and Reforma as well as the dimension of social responsibility consciousness, this inquiry attempted to investigate the relationship of leadership, organization structure, financial resources, personnel, and social responsibility with the performance of local governments. This study likewise tried to ascertain the level of administrative capability and performance of the local governments' mandated functions.

\section{Importance of the Study}

Various sectors of society are expected to benefit from the results of this investigation.

Firstly, policy makers are expected to realize the strengths and weaknesses of the present administrative capability and performance of local governments to serve as bases for crafting policies aimed to enhance their capacities.

Further, national and local government institutions shall be properly guided on the importance of enhancing administrative capability to improve organizational performance. They are counted upon to be able to appreciate the value of enhancing administrative capability and performance in order to improve public services.

Moreover, the general public shall be aware of the thrusts undertaken by local governments to enhance administrative capability and performance aimed at improving services to the citizenry.

Finally, the academic community shall have another body of knowledge to refer to about the intricacies of administrative capability as it relates to the performance of local governments.

\section{Literature Review}

Any endeavor aimed to generate new insights must be connected to past undertakings or current perceptions in order to achieve overall relevance and applicability. The review of relevant literature then provides a better appreciation and wider perspective of the background and main concern of the present investigation.

\subsection{Administrative Capability}

Administrative capability, according to Palekar (2012), is the ability to mobilize inputs and increase their productivity or efficiency. Earlier, Norman Uphoff (1973) postulated that "administrative capability involves efficiency, effectiveness, innovation, and efficacy. Efficiency is related to the conversion of inputs, and outputs, with special attention as to how the inputs are used. Effectiveness relates to the production as to how the inputs are intended to yield certain desired outcomes. Innovation can relate to the whole process, but its key function is to get more outputs to achieve the desired outcomes. Efficacy deals with their achievement, but in extrabureaucratic ways, especially involving inputs from the public so that the output of administration indeed matches-up with public needs."

To ensure success and meaning to the decentralization of authority to the local government units, De Guzman and Reforma (1993) identified the required four dimensions of administrative capability which include (1) leadership, (2) structure, (3) financial resources, and (4) personnel. Social responsibility consciousness, as an 
added dimension of administrative capability, was included in this investigation.

\subsection{Leadership Capability}

De Guzman and Reforma (1993) defined leadership, in the context of decentralization, as the ability not only to deliver services efficiently and effectively with scarce resources, but also to expand public interest in programs locally administered and to obtain financial and technical support from other sources.

Nigro and Nigro (1992) asserted that the essence of leadership is influencing the actions of others; the essential quality of leaders is that they are convinced something must be done, and they persuade others to help them get it done.

On the other hand, Medina (2006) enumerated the three skills of effective leaders which include technical, human relations, and conceptual skills. Technical skills refer to the specialized knowledge needed to perform a job. Human relations skills refer to the ability of the leader to interact with people inside and outside the organization while conceptual skills refer to the ability of a person to think in abstract terms and to see how parts fit together to form the whole.

\subsection{Organization Structure}

Section 3(b) of the Philippine Local Government Code of 1991 declares that there shall be established in every local government unit an accountable, efficient, and dynamic organizational structure and operating mechanism that will meet the priority needs and service requirements of its communities.

Padilla (1992) emphasized the need to restudy organizational structure as a dimension of administrative capability in local governments of the Philippines. He examined three aspects of structure, namely: the problem of duality of government service, organizational differentiation, and the contextual factors influencing organizational structure. De Guzman and Reforma (1993) defined the problem of duality of government service as the simultaneous performance of the same functions by both national government field offices and local government entities. Under the structure created by devolution, national agencies whose functions have been devolved to local government units were allowed to maintain field offices. The personnel not devolved to the local governments continued to perform functions that duplicated those already being performed by the local government units. De Guzman and Reforma added that this duplication appears to be endemic in most agencies; there are field personnel of the different national agencies operating side by side with those of the various local government units.

From the structural-descriptive perspective, Tendero (1993) viewed the structure of the bureaucracy as an organizational arrangement of component elements, each performing functions and roles. The structure is seen as a device for policy administration.

\subsection{Financial Capability}

As provided in the Philippine Local Government Code of 1991, the vesting of duty, responsibility, and accountability in local government units shall be accompanied with provision for reasonably adequate resources to discharge their powers and effectively carry out their functions; hence, they shall have the power to create and broaden their own sources of revenue and the right to a just share in national taxes and an equitable share in the proceeds of the utilization and development of the national wealth within their respective areas (Sec. 3(d), LGC 1991).

Denhardt (1999) stated that public budgeting and financial management are concerned with the allocation of limited resources to the problems governments and other public organizations face. He said public organizations must then carefully and responsibly manage large amounts of money and other resources - taking in taxes and other revenues, purchasing innumerable goods and services, and investing surplus funds or managing debt wisely. He added that in order to manage public programs effectively, one must be able to manage resources, both practically and politically. This is especially significant in the light of the repeated instances of corruption and waste which made more effective control over the public's resources necessary.

In their book Modern Public Administration, Nigro and Nigro (1992) wrote that managers in government must develop strategies and methods for achieving "more" with "less." The "more" refers to providing the additional or better-quality services that citizens request in an ever more complex society. The "less" refers to the reality of the declining financial capacity of governments to provide needed or desirable services.

\subsection{Personnel Capability}

Human resource is considered as the most important asset of an organization. This is attributed to the fact that people can make an organization function even without the presence or availability of the other resources. Abasolo and Ruiz (2004) stressed that "the efficient management of human resources is the competitive key of progressive organizations to be better, faster, more efficient, and ultimately achieve organizational vision, mission and objectives." 
The 1987 Philippine Constitution provides that "appointments in the civil service shall be made only according to merit and fitness to be determined, as far as practicable, and, except to positions which are policydetermining, primarily confidential, or highly technical, by competitive examination."

Pursuant to this constitutional mandate, Section 3(c) of the LGC 1991 states that "subject to civil service law, rules and regulations, local officials and employees paid wholly or mainly from local funds shall be appointed or removed, according to merit and fitness, by the appropriate appointing authority."

It could thus be inferred that only qualified individuals are given the opportunity to serve the government Sison (2003) wrote that an organization must ensure that, at all times, it has in its employ the right number of people with the right skills, assigned to the right jobs where they can contribute most effectively to the productivity and profitability of the organization.

In the same vein, Plunkett and Attner (1992) stressed that "you can have outstanding plans, but if you do not have quality employees to carry out those plans, you are back to square one."

\subsection{Social Responsibility}

Winston Churchill once said that "we make a living by what we get, but we make a life by what we give." Being socially responsible means that people and organizations must behave ethically and with sensitivity toward social, cultural, economic, and environmental issues. Striving for social responsibility helps individuals, organizations, and governments have a positive impact on development, business, and society with a positive contribution to bottom line results (Enevoldson, 2013).

In the words of Medina (2006), "social responsibility refers to the concern of business for the welfare of the society. This indicates that the firm must perform its functions without harming the community, instead it must improve the quality of life. It must produce goods or services that will not adversely affect any component of the society. It can make profits but not to the detriment of society."

Social responsibility in government is subsumed in the Constitutional provision on Accountability of Public Officers which proclaimed that "public office is a public trust. Public officers and employees must at all times be accountable to the people, serve them with utmost responsibility, integrity, loyalty, and efficiency, act with patriotism and justice, and lead modest lives." The Philippine LGC of 1991 also constantly referred to mechanisms to meet the priority needs and service requirements of communities and the improvement of the quality of community life which may be construed as part of the social responsibility of local government units.

\subsection{Performance}

Flores and Abletez (1995) stated that performance is usually equated with local government responses to community for basic or essential services, from capability in decision-making, use of resources (funds, personnel, equipment, etc.), and to delivery of basic public services in a timely and sustained manner. They also quoted an authority in local government administration who said: "the level of local government capability determines its level of performance." Flores and Abletez remarked that the lower the capability, the lower the performance. Capability in governance denotes the capability of a barangay and the local government units to effectively manage or administer local affairs such that performance brings about efficient delivery of basic and essential services to the community.

Shafritz, et al (1992) declared that all public agencies engage in activities that can be identified in terms of the direct results of the work performed. They said that governmental agency outputs are usually aimed at producing broad social consequences; as an agency performs its assigned functions, its activities contribute to social consequences that are at the same time a product of other environmental influences.

Quoting former CSC Chairman Corazon Alma G. De Leon, Buendia and Buendia (2008) enumerated the elements necessary to ensure superior or high performance: (1) a work environment that will nurture productivity, creativity, and outstanding performance; (2) the existence of a compelling or "larger than life vision" that propels or moves the human resources not only to action but also to give meaning to their contributions; (3) leadership is shared; (4) the importance of ensuring that everyone in the organization realizes that he or she is a stakeholder and genuinely participates in the growth of the organization; and (5) the importance of recognizing success, high performance, innovations and discoveries, and celebrating these milestones.

\section{Theoretical Framework}

This investigation substantially relied on Sen's (1979) Capability-based Theory, and the Theory of Organizational Performance of Davis (2013).

The core characteristic of the capability approach is its focus on what people are effectively able to do and to be, that is, on their capabilities. In an organizational setting, the capability-based theory suggests that a firm can achieve competitive advantage through distinctive capabilities possessed by the firm (Grant, 1996). Ulrich (1990) showed the correlation between successful people management and the bottom line. He explained how involving employees in the planning and implementation process and allowing them to see the fruits of their 
labor (the sense of connection between daily work and long-term customer success) benefits the organization.

The Theory of Organizational Performance Management (Davis, 2013) holds that performance management is a set of techniques used to measure success in meeting goals of an organization. The theory of organizational performance management, known as OPM, applies this approach to an organization as a whole, assessing progress toward goals and identifying and adjusting factors which hinder progress.

The Capability Approach is undoubtedly relevant to this inquisition since enhanced leadership capability, organization structure, financial capability, personnel capability and social responsibility consciousness are believed to be associated with improved performance of the local government units.

The application of the Theory of Organizational Performance Management in this study is obvious. The theory is designed to evaluate specific processes and systems and the performance of departments or individual employees of an organization which is the main concern of this investigation. This inquiry attempts to evaluate the association of administrative capability of local government units with their performance.

Administrative capability involves the coordinative and integrative skills necessary for the achievement of the goals of the total organizational system.

It is assumed that an appropriate administrative capability of local government units relates to performance effectiveness. This means that capable leaders, suitable organization structure, adequate financial resources, qualified and trained personnel, and social responsibility consciousness are important factors to ensure the effective performance of local government units.

\section{Methodology}

This study employed the descriptive-co-relational research design.

The researcher conducted this study in the Cordillera Region in northern Philippines, specifically in the provinces of Abra, Benguet, and Mountain Province and the City of Baguio involving total enumeration of the targeted 98 human resource management practitioners who served as respondents.

The human resource management practitioners were selected as respondents since they were perceived to be better equipped to assess the administrative capability and performance of the local governments due to the nature of their functions which include overseeing the proper implementation of the agency performance evaluation system.

A questionnaire served as the primary data gathering tool. Three (3) experts validated the data gathering instrument prior to the scheduled floating of the questionnaires. Validation of the data and information generated ensued through interviews with local government officials. Examination of available documents and other written materials supplemented and complemented the primary data gathering instrument.

Analysis and interpretation of data involved the use of frequency counts and weighted mean relative to the level of administrative capability and performance. In testing the relationships of the selected dimensions of administrative capability and the performance of the local governments, the researcher made use of the Pearson "r" Correlation Coefficient.

\section{Major Findings}

Results of the investigation are elaborated together with an analysis and interpretation of the data generated.

\subsection{Level of Administrative Capability of Local Governments}

Table 1 exhibits the data on the level of administrative capability of local governments.

Table 1. Level of Administrative Capability of Local Governments

\begin{tabular}{|c|c|c|}
\hline Area & $\begin{array}{l}\text { Weighted } \\
\text { Mean }\end{array}$ & $\begin{array}{c}\text { Descriptive } \\
\text { Rating }\end{array}$ \\
\hline a. $\quad$ Leadership Capability & 2.2 & $\mathrm{SC}$ \\
\hline b. Organizational Structure & 2.0 & $\mathrm{SC}$ \\
\hline c. $\quad$ Financial Capability & 2.2 & $\mathrm{SC}$ \\
\hline $\begin{array}{ll}\text { d. } & \text { Personnel capability } \\
\end{array}$ & 1.8 & $\mathrm{SC}$ \\
\hline e. Social responsibility consciousness & 1.9 & $\mathrm{SC}$ \\
\hline Overall Weighted Mean & 2.02 & $\mathrm{SC}$ \\
\hline
\end{tabular}

* Statistical Limit for Weighted Mean and Descriptive Rating: 4.50 - 5.00 - Highly Capable (HC); 3.50

- 4.49 -Capable(C); 2.50 - 3.49 - Moderately Capable (MC); 1.50 - 2.49 - Slightly Capable (SC); 1.00

- 1.49 - Not Capable (NC)

Looking into the level of administrative capability of the local governments, Table 1 indicates that the respondents perceived them as "slightly capable" relative to the dimensions of leadership capability, organization structure, financial capability, personnel capability, and social responsibility consciousness. 
The results manifest a low assessment of the leadership capability of the local government officials. The low rating implies limitations of local officials in the area of specialized knowledge, interactions with people, thinking in abstract terms, and seeing how parts fit together to form a whole if the technical, human relations, and conceptual skills of effective leaders are taken into consideration as forwarded by Medina (2006). The low appreciation of the leadership capability of the local government officials necessitates reforms in the selection, training, and retention process.

The low rating given to the dimension of organization structure connotes a slight defect in the organizational arrangement of component elements in performing specific functions and roles if the organization structure is seen as a device for policy administration as viewed by Tendero (1993). This requires corrective interventions.

In the area of financial capability, the unfavorable rating denotes deficiencies of the local governments in the generation and utilization of allocable financial resources which implies that the immense power and authority vested to them by the Local Government Code of 1991 relative to the exploration of the vast sources of revenues were not properly utilized. Financial capability enhancement programs should now be a priority of the local governments.

The low evaluation of the personnel capability suggests that the personnel were not performing satisfactorily. This insinuates that the local governments have not employed "the right number of people with the right skills, assigned to the right jobs where they can contribute most effectively to the productivity and profitability of the organization (Sison, 2003). As Plunkett and Attner (1992) emphasized, "you can have outstanding plans, but if you do not have quality employees to carry out those plans, you are back to square one." A redirection of the human resource development plans of the local governments should then be a priority.

With a weighted mean of 1.9 , social responsibility consciousness is another dimension of administrative capability which the local governments must improve. The insignificant rating is an indication that there is a lack or absence of programs and projects that are socially desirable or acceptable by the residents including the cultivation of good relations between the local governments and their constituents. As mentioned by Enevoldson (2013), striving for social responsibility helps individuals, organizations, and governments have a positive impact on development, business, and society with a positive contribution to bottom line results.

Overall, the administrative capability of the local governments obtained a mediocre rating which calls for a redirection of strategies aimed to enhance the capability of local governments.

\section{2 Level of Performance of Local Governments}

The data on the level of performance of the local governments are presented in Table 2.

Table 2. Level of Performance of Local Governments

\begin{tabular}{|l|c|c|}
\hline \multicolumn{1}{|c|}{ Performance Indicator } & $\begin{array}{c}\text { Weighted } \\
\text { Mean }\end{array}$ & $\begin{array}{c}\text { Descriptive } \\
\text { Rating }\end{array}$ \\
\hline 1. Enacts \& enforces appropriate number of ordinances \& resolutions & 2.0 & SE \\
\hline $\begin{array}{l}\text { 2. Implements sufficient number of programs and services based on community } \\
\text { needs }\end{array}$ & 1.9 & SE \\
\hline 3. Provides timely programs and services in a sustained manner & 2.0 & SE \\
\hline $\begin{array}{l}\text { 4. Furnishes relevant \& appropriate action to calls for assistance from the } \\
\text { community }\end{array}$ & 1.9 & SE \\
\hline 5. Renders fast, accurate and complete service & 2.0 & SE \\
\hline 6. Makes available a conducive work environment & 1.9 & SE \\
\hline 7. Receives regularly positive feedback from clients & 2.2 & SE \\
\hline 8. Introduces innovative ideas to enhance programs and services & 2.3 & SE \\
\hline 9. Shares leadership & 2.0 & SE \\
\hline 10. Crafted a vision that propels action & 2.2 & SE \\
\hline $\begin{array}{l}\text { 11. Considers members as stakeholders or participants in decision making and other } \\
\text { activities }\end{array}$ & 1.9 & SE \\
\hline 12. Recognizes success, high performance, innovations, and discoveries of members & 1.8 & SE \\
\hline 13. Celebrates exemplary performance milestones & 2.1 & SE \\
\hline & 2.0 & SE \\
\hline
\end{tabular}

* Statistical Limit for Weighted Mean and Descriptive Rating: 4.50 - 5.00 - Highly Effective (HE); 3.50 -

4.49 -Effective (E); 2.50 - 3.49 - Moderately Effective (ME); 1.50 - 2.49 - Slightly Effective (SE); 1.00 -

1.49 - Not Effective (NE)

The respondents perceived the performance of the local governments as "slightly effective" with an overall weighted mean of 2.0. As shown in Table 2, all of the performance indicators obtained a rating of "slightly 
effective" or below average performance. The lowest indicator suggests that the local governments lack recognition of success, high performance, innovations, and discoveries of employees as expressed by Buendia and Buendia (2008) in quoting former CSC chairperson Corazon Alma de Leon. This means that the local governments fell short of the people's expectations in the implementation or provision of desired programs and services. The implementation then of a workable performance management system in the local governments becomes paramount.

\subsection{Relationship between Administrative Capability and Performance of Local Governments}

The data generated on the correlation of administrative capability and performance of local governments are shown in Table 3.

Table 3. Correlation of Administrative Capability and Performance of Local Governments

\begin{tabular}{|l|l|l|l|l|}
\hline Indicators & $\begin{array}{l}\text { Pearson } \mathrm{r} \\
\text { Coefficient }\end{array}$ & Interpretation* & $\begin{array}{l}\text { p- } \\
\text { value** }\end{array}$ & Remarks \\
\hline $\begin{array}{l}\text { Leadership Capability x } \\
\text { Performance }\end{array}$ & .634 & $\begin{array}{l}\text { Moderate positive } \\
\text { correlation }\end{array}$ & .004 & $\begin{array}{l}\text { Highly } \\
\text { Significant }\end{array}$ \\
\hline $\begin{array}{l}\text { Organizational Structure x } \\
\text { Performance }\end{array}$ & .552 & $\begin{array}{l}\text { Moderate positive } \\
\text { correlation }\end{array}$ & .013 & Significant \\
\hline Financial Resources x Performance & .829 & $\begin{array}{l}\text { High Positive } \\
\text { Correlation }\end{array}$ & .000 & $\begin{array}{l}\text { Highly } \\
\text { Significant }\end{array}$ \\
\hline $\begin{array}{l}\text { Personnel Capability x } \\
\text { Performance }\end{array}$ & .751 & $\begin{array}{l}\text { High Positive } \\
\text { Correlation }\end{array}$ & .000 & $\begin{array}{l}\text { Highly } \\
\text { Significant }\end{array}$ \\
\hline $\begin{array}{l}\text { Social Responsibility x } \\
\text { Performance }\end{array}$ & .960 & $\begin{array}{l}\text { Very High Positive } \\
\text { Correlation }\end{array}$ & .000 & $\begin{array}{l}\text { Highly } \\
\text { Significant }\end{array}$ \\
\hline $\begin{array}{l}\text { Overall Administrative Capability } \\
\text { x Performance }\end{array}$ & .843 & $\begin{array}{l}\text { High Positive } \\
\text { Correlation }\end{array}$ & $\begin{array}{l}\text { Highly } \\
\text { Significant }\end{array}$ \\
\hline
\end{tabular}

Table 3 divulges the significant relationship between administrative capability and performance of local governments with an overall value of .843 , interpreted as high positive correlation as supported by the "p" value of .000 which is highly significant even at .01 level. The table also reveals that social responsibility has a significant perfect correlation with performance which suggests that the sense of social responsibility of the local governments is the most significant dimension of administrative capability that relates to performance. The table likewise shows that financial capability has a significant relationship with performance while organization structure has the least significance to performance. In general, as administrative capability improves, performance gets better. This validates the claim of Flores and Abletez (1995) who wrote that the level of local government determines its level of performance; the lower the capability, the lower the performance.

\section{Conclusion}

This study explored the level and correlation of administrative capability and performance of local governments in the mountain region of northern Philippines. The results indicated a low regard for the conceptual, technical, and human relations skills of local government leaders. The respondents also gave a low rating for the local governments' organization structure, income generating capacity, personnel capability, and social responsibility consciousness. The results likewise revealed that the respondents perceived the performance of the local governments as "slightly effective." The tests conducted manifested a significant positive relationship between administrative capability and performance of local governments. The results denote that when administrative capability is enhanced, performance also improves. Social responsibility consciousness proved to be the most significant dimension that was linked to performance while the least significant was organization structure. The findings imply that the local governments can deliver services no matter what the organization structure is for as long as they have a strong sense of social responsibility.

The unfavorable findings necessitate the enhancement of the administrative capability of the local governments through the installation of a mechanism for selecting, developing, and training qualified and capable elective and appointive officials and employees; engaging the services of expert financial advisors to improve their resource generation capability; involving the citizens in decision-making relative to the planning and implementation of programs and services to ensure their social desirability; and elevating the project planning and implementation skills of the officials and employees.

The local governments should now explore other avenues in generating additional revenues in order to lessen too much reliance on the Internal Revenue Allotment and subsequently elevate them to a higher income classification that will eventually benefit their constituents in terms of programs and services like in the area of program or project packaging for possible funding by foreign or local donors.

The frontline service providers should also undergo re-training on how to properly deal with their clients in 
order to raise the quality of the services.

A citizen's forum should likewise be a regular undertaking of the local governments during the planning and implementation process of a program or service.

\section{References}

Abasolo, Pacita A. \& Maria Anita V. Ruiz. (2004). Personnel/Human Resource Management and Labor Relations. GIC Enterprises \& Co., Inc., p. 1.

Aralar, Reynaldo B. (2009). Administrative Law Simplified. M: National Bookstore, pp. 246, 250-252.

Altmann, J., et al. (2000). The UNDP Role in Decentralization and Local Governance: A Joint UNDPGovernment of Germany Evaluation. Governance for Sustainable Human Development, p. 19.

Buendia, Daisy P. \& Daniel T. Buendia. (2008). Personnel Administration in the Philippine Government. M: National Bookstore, p. 155.

Corpuz, Crispina R. Human Resource Management. (2006). Revised Ed. M: Rex Bookstore, Inc.

De Guzman, Raul P. \& Mila A. Reforma. (1993). Decentralization Towards Democratization and Development in the Asia Pacific Region. Local Government in the Philippines: A Book of Readings, Vol. 1, Local Government Academy, CLRG \& UP-NCPAG.

Denhardt, Robert B. (1999). Public Administration: An Action Orientation. $3^{\text {rd }}$ ed., Fl: Harcourt, Inc., p. 149.

Enevoldson, Naomi. (2013). What is Social Responsibility. StudioPress-WordPress.

Flores, C. O. \& J. P. Abletez. (1995). Barangay: Its Government and Management. Revised Ed., QC: Mary Jo Educational Supplies.

Grant, Robert M. (1996). Prospering in Dynamically Competitive Environments: Organizational Capability as Knowledge Integration in Organization Science, Vol. 7, No. 4, pp. 375-387.

Green, Keith. (2005). Decentralization and Good Governance: The Case of Indonesia. MPRA_Paper_18097_pdf. Katz, Saul M. (2010). A Methodological Note on Appraising Administrative Capability for Development in Appraising Administrative Capability for Development. pp. 99-100.

Medina, Roberto G. (2006). Business Organization and Management. M: Rex Bookstore, Inc.

Nigro, Felix A. \& Lloyd G. Nigro. (1992). Modern Public Administration. $7^{\text {th }}$ ed., NY: Harper \& Row Publishers, pp. $178,211$.

Padilla, P. L. (1992). Strengthening Local Government Administration and Accelerating Local Development. Local Government Center, UP-CPA \& Asia Foundation Philippines.

Palekar, S. A. Development Administration. (2012). PHI Learning Pvt. Ltd., p. 178

Plunkett, Warren R. \& Raymond F. Attner. (1992). Introduction to Management. B: PWS-Kent Publishing Co., p. 290

Tendero, Avelino P. (1993). Theory and Practice of Public Administration in the Philippines. Makati: FAFI, p. 7.

Sen, Amartya. (1999). Development as Freedom. Oxford University Press.

Shafritz, Jay M., et al. (1992). Personnel Management in Government. $4^{\text {th }}$ ed. NY: Marcel Dekker, Inc., p. 417.

Sibal, Jose Agaton R. (1996). Local Government Code (As Amended), $2^{\text {nd }}$ Ed., M: Central Book Supply, Inc., pp. 2-3.

Sison, Perfecto S. (2003). Personnel Management in the $21^{\text {st }}$ Century. $7^{\text {th }}$ ed., M: Rex Bookstore, Inc., p. 40.

Ulrich, Dave. (1990). Organizational Capability: Competing from the Inside Out. John Wiley \& Sons.

Uphoff, Norman. (1973). An Analytical Model of Process and Performance for Developing Indicators of Administrative Capability. Philippine Journal of Public Administration, Vol. XVII, No. 3, pp. 372-379. 